\title{
Genetic variation in capelin Mallotus villosus from Norwegian waters*
}

\author{
J. Mork ${ }^{1}$ and E. Friis-Sörensen ${ }^{2}$ \\ 1 Biological Station, Hans Hagerupsgate 6, 7000 Trondheim, Norway \\ 2 Institute of Fisheries, University of Tromsö, P.O. Box 790, 9001 Tromsö, Norway
}

\begin{abstract}
Capelin Mallotus villosus from the large oceanic Barents Sea stock and from a local northern Norwegian fjord stock were sampled during 1981 and 1982. Tissue extracts from white skeletal muscle, heart, and liver were analyzed by isoelectric focusing and histochemical enzyme detection. Staining for 11 enzymes revealed at least 20 loci, of which 18 are considered suitable for routine population genetic studies. Tissue distributions, banding patterns, and pI values of the isozymes are described. The frequency of polymorphic loci $\left(P_{0.99}\right)$ was $0.22 \pm 0.10$ and the average heterozygosity per locus $\left(\bar{H}_{L}\right)$ was $0.008 \pm 0.007$. Inter-sample differences in allele frequencies at 4 polymorphic loci were not significant and thus did not indicate genetic isolation between the fjord stock and the oceanic stock.
\end{abstract}

\section{INTRODUCTION}

The Atlantic capelin Mallotus villosus is mainly distributed in Arctic regions; it is abundant in the Barents Sea, at Jan Mayen, north Iceland and Greenland, and on the east coast of North America. Being a shoaling pelagic species, the capelin spends most of the year feeding on plankton in productive areas of the open seas. Specimens mature at an age of 2 to 4 yr ( 15 to 20 $\mathrm{cm})$, and migrate in large shoals to the coast for spawning during late winter, spring and early summer. The eggs are benthic.

The capelin is of utmost importance as a prey species, e.g. for birds, whales, salmon, coalfish, and cod. It is also harvested by man, and the annual landings are of great economic importance. A comparatively large stock feeds in the Barents Sea and spawns on the coast of Murmansk and northern Norway (Fig. 1). Also, in several fjords of northern Norway, what seem to be smaller, local stocks, are present. It is not known whether these fjord stocks are reproductively isolated from each other or from the large oceanic stock.

It is widely accepted that knowledge of population structure is a major prerequisite for rational utilization

\footnotetext{
- Contribution No. 213, Biological Station, Trondheim Norway
}

of fish resources. In many cases, population genetic methods involving electrophoretic analyses have been successfully applied to the study of fish population structure (e.g. Allendorf and Utter, 1979, and references therein). The benefits of using a large number of loci in such studies have often been pointed out (e.g. Nei and Roychoudhury, 1972; Nei, 1973; Lewontin, 1974). With respect to the capelin, there has been lack of information on the amount and distribution of electrophoretically detectable genetic variation which could serve as a basis for routine population genetics surveys.

The intention of the present study was to obtain estimates of the general level of genetic variability in the capelin and to characterize a set of tissue enzyme loci which could be utilized in stock structure studies. Simultaneously, information was sought on the genetic relationship between a presumed local fjord stock and the large oceanic Barents Sea stock of capelin.

\section{MATERIALS AND METHODS}

\section{Sample collections}

Specimens of capelin Mallotus villosus were captured by trawling in Area A (fjord stock) and Area B (oceanic stock) in 1981 and 1982 (Fig. 1). Tissue sam- 
ples (white skeletal muscle, heart, and liver) were immediately cut out and stored at $-25^{\circ} \mathrm{C}$ until analysis, which was carried out within $1 \mathrm{mo}$. Initially, at least 60 specimens from each location were analyzed

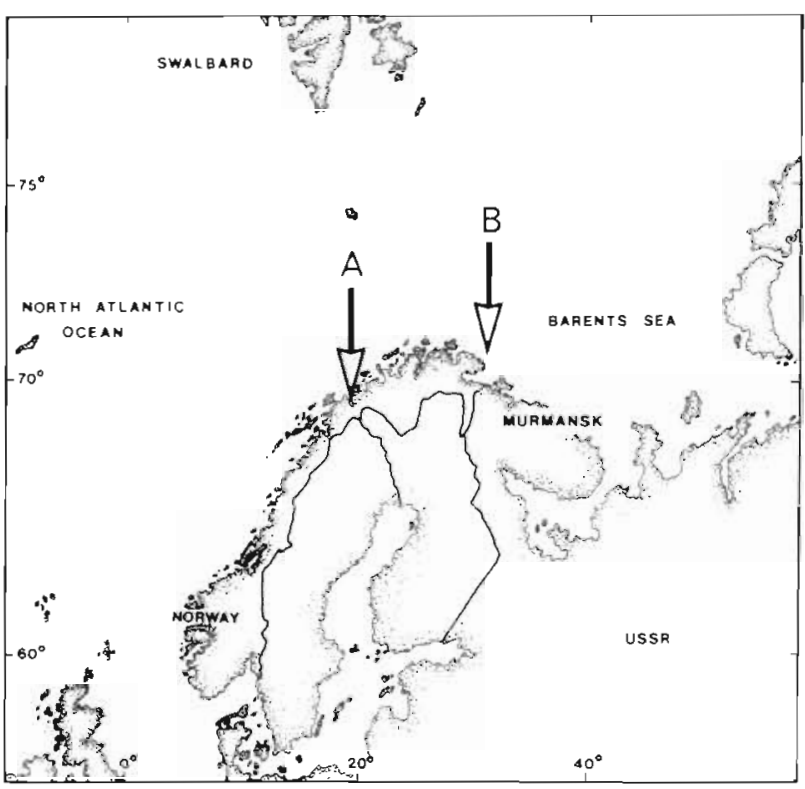

Fig. 1. Map of the North East Atlantic Ocean and adjacent areas with capelin sampling locations. Area A: Balsfjord stock, Area B: Barents Sea oceanic stock

for all loci. For the loci which showed genetical polymorphisms, an additional 10 or 60 specimens, depending on the enzyme, from Area A were analyzed.

Experimental setup, analytical procedures and biochemical genetic nomenclature employed follow Mork and Haug (1983) and are thus only briefly reviewed here.

\section{Analytical procedures and equipment}

Tissue extracts were prepared by grinding partly thawed samples in equal volumes of a $1 \%$ solution of the carrier ampholyte to be used in the electrofocusing. The homogenates were centrifuged (15 min, 10,000 G, $0{ }^{\circ} \mathrm{C}$ ) and the clear supernatants absorbed in pieces of filter paper (Gelman Absorbant Sheets; part No. 51290) for subsequent application on the gels.

The isoelectric focusing was performed in $240 \times 125 \times 0.7 \mathrm{~mm}$ laboratory-made polyacryleamide gels ( $\mathrm{T}=5 \%, \mathrm{C}=3 \%$, Bis-crosslinked and photopolymerized) cast between glass plates on to a specially treated polyester film (Gelfix ${ }^{\circledR}$, Serva).

The isoelectric focusing equipment was basically the LKB Multiphor system, modified for simultaneous running of 8 gels. The electrode distance was $100 \mathrm{~mm}$ $1 \mathrm{~mol} 1^{-1}$ phosphoric acid and 1 mol $1^{-1}$ sodium hydroxide were used as anolyte and catholyte, respectively, for the mostly employed ampholyte blending; Servalyte ${ }^{8}$ 4-9 T. The electrode solutions were absorbed in $230 \times 10 \mathrm{~mm}$ strips cut from Gelman Absorbant Sheets. The electrical settings were $0.08 \mathrm{~W}$ $\mathrm{cm}^{-2} \mathrm{gel}, \mathrm{V}_{\max }=1600$. In routine analysis, the coolant was thermostatted at $4^{\circ} \mathrm{C}$. The filter paper pieces containing tissue extracts were applied to the gel after 15 min of prefocusing by anodal application (approximately $30 \mathrm{~mm}$ from the anode) and $10 \mathrm{~min}$ by cathodal application (approximately $10 \mathrm{~mm}$ from the cathode). They were removed after 20 and 10 min further run, respectively. Total focusing time for gels containing $1.8 \%$ Servalyte $4-9 \mathrm{~T}$ was $2 \mathrm{~h}$. Usually 50 individual capelin samples were analysed on each gel.

Enzyme visualization was performed by incubating gels at 20 to $40^{\circ} \mathrm{C}$ in freshly prepared specific staining solutions. The staining recipes generally followed Allendorf et al. (1977) but with some modifications: except for the G6PDH-containing staining solutions (PGI and PGM) which were applied as solid agar overlays, the staining bath buffer was $0.5 \mathrm{~mol}^{-1}$ pure Tris base. The resulting high $\mathrm{pH}$ in the incubation bath generally improved the detection sensitivity and provided more distinct zymograms. When staining for dehydrogenases at such high $\mathrm{pH}_{1}$ the usually employed electrone carrier PMS (Phenazine methosulphate) was replaced by the more stable PES (Phenazine ethosulphate).

When sufficiently distinct zymograms had developed (1 to $30 \mathrm{~min}$ depending on enzyme activity), the reaction was stopped in $20 \% \mathrm{TCA}$. The gels were preserved for future reference by partly drying and overlaying with polyester sheets.

Approximate pI values of isozyme bands were obtained by comparing their gel positions with those of a set of reference proteins with known pIs run on the same gel. In such experiments the coolant temperature was manipulated so that the gel temperature towards the end of the focusing was $4{ }^{\circ} \mathrm{C}$ measured with a thermocouple on the gel surface.

\section{Zymogram interpretation and nomenclature}

When interpreting electrophoretic banding patterns we follow the principles outlined by Allendorf et al. (1977). Apart from the use of $\mathrm{pI}$ values instead of relative electrophoretic mobilities, our designation of loci, alleles, and genotypes follows the system suggested by Allendorf and Utter (1979). Notes on subunit structure of proteins are based on Darmall and Klotz (1975). 


\section{RESULTS}

Staining for 11 different enzymes revealed a minimum number of 20 loci according to our interpretations. Of these, 18 could be reliably scored and are considered suitable for routine population genetics surveys. The main results from the electrophoretic analyses are compiled in Table 1.

\section{Description of enzymes}

AAT. Two well separated regions of AAT activity were observed on the gels. The most cathodic region contained 3 to 4 faint bands with pIs between 8.2 and 8.9. The bands in this region were attributed to AAT-1 which seemed to be slightly more active in liver than in muscle and heart tissue. Another, more heavily staining region of AAT activity displayed distinct bands which could be reliably scored. This region of activity was attributed to AAT-2. The normal AAT-2 pattern, consisting of 5 to 6 anodal satellites to the main band which pl was 5.6, was observed in all 3 tissue types. Putative heterozygotes AAT-2(5.6/5.8) displayed the typical dimeric $1: 2: 1$ staining ratios and interdistances of bands.

a-GPDH. Noticeable a-GPDH activity was observed only in muscle- and liver extracts. Two loci are postulated to account for the observed patterns. a-GPDH-1 was manifested in both muscle and liver, while aGPDH-2 could be scored only from liver extracts, which additionally showed the supposed inter-locus hybrid band. Diffuse anodic subbanding was observed at a-GPDH-1.

Table 1 Mallotus villosus. Results from isoelectric focusing and specific enzyme detection in muscle (M), heart (H), and liver (L) extracts. Relative activity in the various tissues: ${ }^{\prime}{ }^{\prime}$ strong, ${ }^{\prime}$ intermediate, ${ }^{\prime}$ weak enzyme activity. D. B. = diffuse banding pattern, A.S. = anodal subbanding, M.B. = multiple bands

\begin{tabular}{|c|c|c|c|c|c|c|c|c|c|c|}
\hline Protein & $\begin{array}{l}\text { Abbre- } \\
\text { viation }\end{array}$ & $\begin{array}{l}\text { E.C. } \\
\text { No. }\end{array}$ & $\begin{array}{l}\text { Locus } \\
\text { design } \\
\text { (If }>1)\end{array}$ & $\begin{array}{r}\text { A } \\
M\end{array}$ & $\begin{array}{l}\text { Activit } \\
\text { in } \\
\mathrm{H}\end{array}$ & $\mathrm{L}$ & $\begin{array}{l}\text { Polymor- } \\
\text { phic }\end{array}$ & $\begin{array}{l}\text { Obs. } \\
\text { No. of } \\
\text { alleles }\end{array}$ & $\begin{array}{l}\text { Approx. pI } \\
\text { (at } 4^{\circ} \mathrm{C} \text { ) }\end{array}$ & $\begin{array}{l}\text { Com- } \\
\text { ments }\end{array}$ \\
\hline $\begin{array}{l}\text { Aspartate } \\
\text { aminotransferase }\end{array}$ & AAT & 2.6.1.1 & $\begin{array}{l}1 \\
2\end{array}$ & $\therefore$ & $\therefore$ & $\cdot$ & $\begin{array}{l}? \\
\text { Yes }\end{array}$ & $?$ & $\begin{array}{r}8.2-8.9 \\
5.6 ; 5.8\end{array}$ & $\begin{array}{l}\text { D. B. } \\
\text { A.S. }\end{array}$ \\
\hline $\begin{array}{l}\text { a-glycerophosphate } \\
\text { dehydrogenase }\end{array}$ & a-GPDH & 1.1 .1 .8 & $\begin{array}{l}1 \\
2\end{array}$ & $\cdot$ & & $\ddot{*}$ & $\begin{array}{l}\text { No } \\
\text { No }\end{array}$ & $\begin{array}{l}1 \\
1\end{array}$ & $\begin{array}{l}7.1 \\
5.5\end{array}$ & $\begin{array}{l}\text { A.S. } \\
\text { A.S. }\end{array}$ \\
\hline $\begin{array}{l}\text { Glucose-6-phosphate } \\
\text { dehydrogenase }\end{array}$ & G-6PDH & 1.1 .1 .49 & & & & $\cdot$ & $?$ & $?$ & $4.9-5.3$ & D. B. \\
\hline $\begin{array}{l}\text { Isocitrate } \\
\text { dehydrogenase }\end{array}$ & IDH & 1.1 .1 .42 & $\begin{array}{l}1 \\
2\end{array}$ & $\dot{\cdot}$ & $\dot{.}$ & $\cdots$ & $\begin{array}{l}\text { No } \\
\text { No }\end{array}$ & $\begin{array}{l}1 \\
1\end{array}$ & $\begin{array}{l}7.1 \\
6.3\end{array}$ & A.S. \\
\hline $\begin{array}{l}\text { Lactate } \\
\text { dehydrogenase }\end{array}$ & $\mathrm{LDH}$ & 1.1 .1 .27 & $\begin{array}{l}1 \\
2 \\
3\end{array}$ & $\begin{array}{l}\cdots \\
\cdots\end{array}$ & $\begin{array}{l}\cdots \\
\cdots\end{array}$ & $\dot{\dot{r}}$ & $\begin{array}{l}\text { No } \\
\text { No } \\
\text { No }\end{array}$ & $\begin{array}{l}1 \\
1 \\
1\end{array}$ & $\begin{array}{l}7.8 \\
6.8 \\
5.6\end{array}$ & \\
\hline $\begin{array}{l}\text { Malate } \\
\text { dehydrogenase }\end{array}$ & $\mathrm{MDH}$ & 1.1 .1 .37 & $\begin{array}{l}1 \\
2 \\
3\end{array}$ & $\begin{array}{l}\cdots \\
\cdots\end{array}$ & $\begin{array}{l}\cdots \\
\cdots \\
\cdots\end{array}$ & $\cdots$ & $\begin{array}{l}\text { Yes } \\
\text { No } \\
\text { No }\end{array}$ & $\begin{array}{l}3 \\
1 \\
1\end{array}$ & $\begin{array}{r}7.9 ; 8.7 ; 8.8 \\
7.1 \\
5.6\end{array}$ & \\
\hline Malic enzyme & ME & 1.1 .1 .40 & & • & • & $\cdots$ & No & 1 & $5.5-6.0$ & M.B. \\
\hline $\begin{array}{l}\text { Phosphogluco- } \\
\text { isomerase }\end{array}$ & PGI & 5.3 .1 .9 & $\begin{array}{l}1 \\
2\end{array}$ & $\cdots$ & $\cdot$ & $\cdots$ & $\begin{array}{l}\text { No } \\
\text { Yes }\end{array}$ & $\begin{array}{l}1 \\
5\end{array}$ & $\begin{array}{r}7.2 \\
6.5 ; 6.8 ; 6.9 ; 7.0 ; 8.4\end{array}$ & \\
\hline $\begin{array}{l}\text { Phosphogluco- } \\
\text { mutase }\end{array}$ & PGM & 2.7 .5 .1 & $\begin{array}{l}1 \\
2\end{array}$ & $\cdots$ & $\cdots$ & $\cdot$ & $\begin{array}{l}\text { No } \\
\text { No }\end{array}$ & $\begin{array}{l}1 \\
1\end{array}$ & $\begin{array}{l}5.7 \\
6.0\end{array}$ & $\begin{array}{l}\text { A.S. } \\
\text { A.S. }\end{array}$ \\
\hline $\begin{array}{l}\text { Polyol dehydro- } \\
\text { genase (unspec.) }\end{array}$ & $\mathrm{PDH}$ & & & & $\cdot$ & $\cdots$ & No & 1 & 5.7 & \\
\hline $\begin{array}{l}\text { Superoxide } \\
\text { dismutase }\end{array}$ & SOD & 1.15 .1 .1 & & $\cdots$ & $\cdots$ & $\cdots$ & Yes & 2 & $5.5 ; 6.1$ & \\
\hline
\end{tabular}




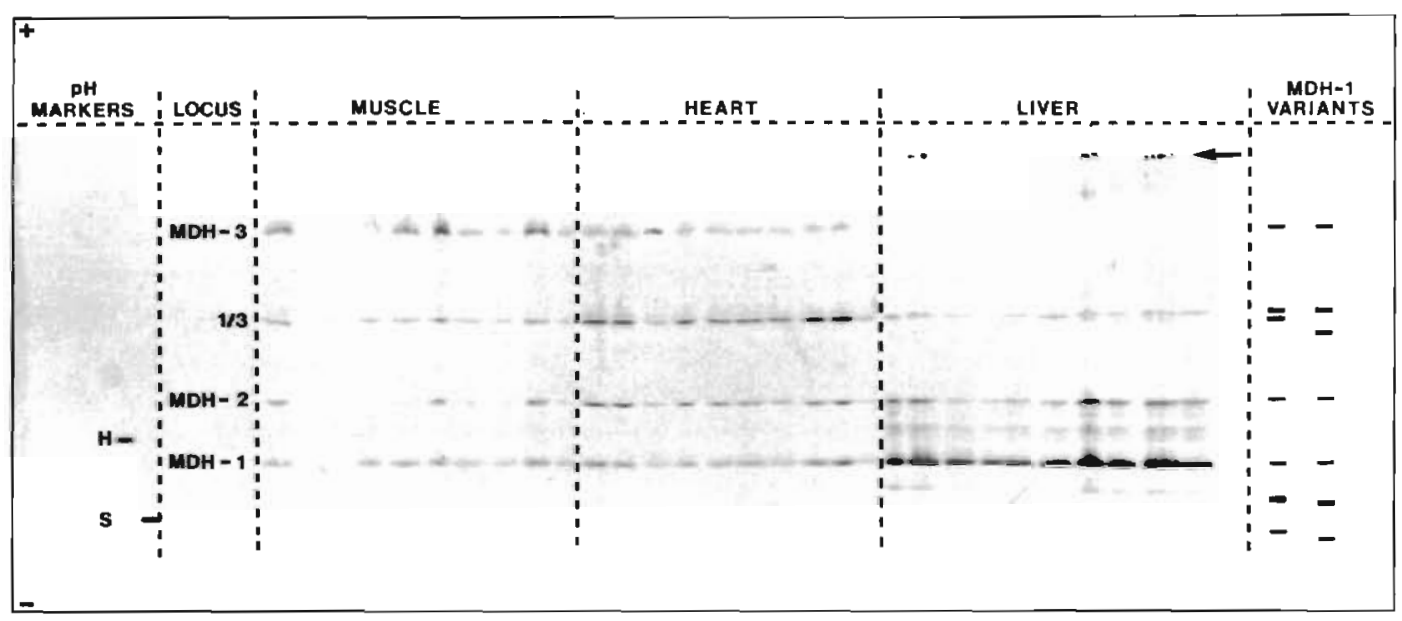

Fig. 2. Capelin Mallotus villosus. MDH zymograms with genetic interpretation and drawing of observed variant patterns. Site of sample application indicated by arrow. Specimen No 1 to 10 from left in each cell, with application artifact in muscle Samples 2 and 3 . The skew position of the inter-locus hybrid band $1 / 3$ is caused by non-linearity of the pH-gradient (Servalyte $4-9 \mathrm{~T}$ ). $\mathrm{H}$ and $\mathrm{S}$ are horse- and sperm whale myoglobins, respectively. (Photo P. E. Fredriksen)

G-6PDH. Only liver extracts showed activity for this enzyme with several diffuse bands in the $\mathrm{pI}$ range 4.9 to 5.3 in which no qualitative variation was observed. However, the activity was weak and variable and no conclusions could be drawn as to the genetic control of this enzyme in the capelin.

IDH. Muscle and heart extracts produced identical IDH zymograms; one distinct band with $\mathrm{pI}=6.3$ and multiple, qualitatively invariable anodic sub-bands which increased in density after storage and thus are believed to be post-transcriptional modifications of the coded protein. We suggest that 1 monomorphic locus, $I D H-2$, is responsible for this pattern. In liver extracts, additional bands were observed cathodal to the muscle/heart patterns; one band with $\mathrm{pI}=7.1$ and another with $\mathrm{pI}=6.7$. We suggest the former to be the homodimeric product of subunits coded at $I D H-1$ and the latter to be the interlocus hybrid molecule between IDH-1 and IDH-2. No qualitative variation was observed at IDH-2 in our material.

LDH. We postulate 3 loci to explain the observed $\mathrm{LDH}$ patterns. What are supposed to be inter-locus

Table 2. Mallotus villosus. Observed number of genotypes at 4 polymorphic enzyme loci. Individual sample values and joint values. No deviation from expected genotypic proportions under genetic equilibrium was observed

\begin{tabular}{|c|c|c|c|c|c|c|c|}
\hline Locus & Sampling location & \multicolumn{5}{|c|}{ Observed genotypes } & $N$ \\
\hline \multirow{4}{*}{$A A T-2$} & & $5.6 / 5.6$ & $5.6 / 5.8$ & & & & \\
\hline & Balsf jord & 114 & 6 & & & & 120 \\
\hline & Barents Sea & 59 & 1 & & & & 60 \\
\hline & Total & 173 & 7 & & & & 180 \\
\hline \multirow{4}{*}{$M D H-1$} & & $7.9 / 7.9$ & $7.9 / 8.7$ & $7.9 / 8.8$ & & & \\
\hline & Balsfjord & 68 & 1 & 1 & & & 70 \\
\hline & Barents Sea & 58 & 1 & 1 & & & 60 \\
\hline & Total & 126 & 2 & 2 & & & 130 \\
\hline \multirow{4}{*}{$P G I-2$} & & $6.8 / 6.8$ & $6.8 / 6.5$ & $6.8 / 6.9$ & $6.8 / 7.0$ & $6.8 / 8.4$ & \\
\hline & Balsfjord & 64 & 2 & 0 & 2 & 2 & 70 \\
\hline & Barents Sea & 57 & 0 & 1 & 2 & 0 & 60 \\
\hline & Total & 121 & 2 & 1 & 4 & 2 & 130 \\
\hline \multirow{4}{*}{$S O D$} & & $6.1 / 6.1$ & $6.1 / 5.5$ & & & & \\
\hline & Balsfjord & 118 & 2 & & & & 120 \\
\hline & Barents Sea & 60 & 0 & & & & 60 \\
\hline & Total & 178 & 2 & & & & 180 \\
\hline
\end{tabular}


hybrid molecules were present in the expected configurations. In our samples, all LDH loci were monomorphic.

$\mathrm{MDH}$. Our genetic interpretation of $\mathrm{MDH}$ patterns (Fig. 2) is provisional. The band cathodal to MDH-1 may be the inter-locus heterodimer between $\mathrm{MDH}-1$ and a weakly expressed (not visible on gels) more anodal locus. The status of the band attributed to $M D H-2$ in Fig. 2 is also uncertain. If an additional cathodal locus exists, the present MDH-2 band might be an inter-locus hybrid band. However, it might also be a secondary modification of the present $\mathrm{MDH}-1$ molecule. Upon prolonged staining the MDH-3 bands were faintly visible also in liver zymograms. Pending further analyses we postulate $3 \mathrm{MDH}$ loci to account for our observations. The supposed heterozygotes at $M D H-1$ showed the typical $1: 2: 1$ staining ratio.

ME. When staining for ME (using NADP as cofactor) a set of bands apparently identical to the $\mathrm{MDH}$ patterns occurred simultaneously on the gels. Neglecting these, the pIs of the remaining bands, which is assumed to be caused by $\mathrm{ME}$, were distributed between 5.5 and 6.0. Up to 20 closely spaced bands were observed in all tissues but most predominantly in liver. No qualitative variation could be observed and we conservatively postulate 1 monomorphic ME locus to account for our observations.

PGI. We postulate 2 loci to be responsible for the observed patterns of PGI activity in the different tissues. PGI-1 isozymes were most abundant in liver extracts but were also represented in heart, while PGI2 was active in all 3 tissues. PGI-1 appeared monomorphic but several 3-banded variant patterns were observed for PGI-2 in the expected dimeric staining ratios (only heterozygotes being observed, cf. Table 2). The pI of the main band in the PGI-1 zone was 7.2, while the pI of the most common band in the PGI-2 region was 6.8 , with variant homodimer bands situated at pIs $6.5,6.9,7.0$ and 8.4 .

PGM. We postulate 2 loci coding for PGM in the investigated tissues. $P G M-2$ was equally expressed in all tissues, while noticeable PGM-1 activity was observed only in muscle and liver. No variants were observed, and we consider both PGM loci to be monomorphic.

PDH. Identical patterns were observed when staining for this NAD-dependant enzyme whether the substrate employed was Xylitol, Sorbitol, or Glucitol. One distinct band of activity, $\mathrm{pI}=5.7$, was observed in liver extract zymograms. This band was also present, although faint, in heart zymograms. The locus coding for this rather unspecific dehydrogenase appeared monomorphic in the present samples.

SOD. SOD activity was observed in all tissues; 1 distinct band with $\mathrm{pI}=6.1$ was usually observed, but in 2 individuals the expected pattern of a heterozygote for this dimeric enzyme was observed. The pI of the variant homodimer was 5.5 .

\section{DISCUSSION}

Compared to analyses, e.g. by starch gel electrophoresis, there is a danger that in isoelectric focusing studies the number of loci coding for each protein may be underestimated, particularly when the functional products are monomers (which do not have interlocus hybrid molecules). This is because proteins focusing towards the extremes of broad pH gradients may denature and remain undetected, e.g. by zymogram techniques (cf. a case of PGI in Mork and Haug, 1983). Also, the present tissue repertory may be insufficient for the mapping of complete loci sets in the capelin, since significant tissues, e.g. eye and brain, were not investigated. With these restrictions, the present locus repertory should provide a set of randomly chosen genes from which measures of genetic variability can be estimated.

\section{Level of genetic variability}

Our quantitative estimates of genetic variability in the capelin are based on the loci listed in Table 1 except for $A A T-1$ and G-6PDH, at which genotypes could not be reliably scored.

Genetic variation was detected at 4 out of the remaining 18 loci. Employing the 0.99 criterion of polymorphism, the frequency of polymorphic loci $\left(P_{0.99}\right)$ was thus $0.22 \pm 0.010$. However, allele frequencies were always extreme; in all cases the most common allele contributed more than $95 \%$ of the genes at polymorphic loci. This is reflected in the low average heterozygosity per locus; $\overline{\mathrm{H}}_{\mathrm{L}}=0.008 \pm 0.007$, which is very low compared to the mean value in teleosts; about 0.05 (Nevo, 1978). The capelin belongs to family Osmeridae in suborder Osmeroidea of Salmoniformes Another suborder, Salmonoidea, contains, inter alia, family Salmonidae. Cross and Ward (1980) suggested that the comparatively low levels of genetic variability in the salmonids (mean of $\overline{\mathrm{H}}_{\mathrm{L}}$ was about 0.03 ) could be explained as effects of population bottlenecks during glaciations, and the tendency among many salmonids to form small, distinct populations. However, such traits are not characteristic for the history and biology of the capelin, which nevertheless seems to possess even lower amounts of gene variation than salmonids.

Low levels of genetic variability have also been shown to be positively correlated to a relative constancy of environmental factor intensities (Nevo, 1978). 
Significant abiotic factors (temperature, salinity, $\mathrm{O}_{2}-$ content) show only limited seasonal and geographical variation in the environment of the capelin. Thus the values of $\mathrm{P}$ and $\overline{\mathrm{H}}_{\mathrm{L}}$ in this study behave as expected under such a correlation.

For the purpose of studying potential correlations between genetic variability and niche width, fish species have been classified as either habitat specialists or generalists, and measures of gene diversity in these 2 groups have been compared. Results from such comparisons were reported by, e.g. Nevo (1978) and Smith and Fujio (1982), who, however, arrived at different conclusions: In the former study, habitat specialists showed low, and generalists high genetic variation, while in the latter the pattern was opposite. However, as discussed by Smith and Fujio (1982), much of the discrepancy might be contributed to different classification criteria, the choice of which can be rather subjective. Salmoniform species were not represented among the 106 teleosts included in the review by Smith and Fujio (1982). However, by the criteria employed there, the capelin would probably be classified as a habitat generalist and thus conform to the general trend in the materials processed by these authors. A number of additional correlations were presented as subordinate to the general specialistgeneralist effect by Smith and Fujio (1982): Besides a locus repertory effect (genes coding for structural proteins were less variable than genes at enzyme loci), they also noted heterozygosity variation, e.g. between life zones (polar, temperate, tropic), and taxonomical units (order, family) of fishes. A polar distribution, like that of the capelin, was connected with low heterozygosity. As concerns the taxonomical effect, no other osmerids have hitherto been investigated for genetic variation; the closest relatives for which such data exist seem to be the salmonids which, as already mentioned, in general display low values of $\bar{H}_{L}$ (Cross and Ward, 1980, and references therein). In sum, the present capelin data fit well to general trends as outlined by Smith and Fujio (1982).

The distribution of the genetic variation on a finer taxonomic scale was investigated by Ryman (1983) in a comparative study on 4 salmonid species. It was shown that the hierarchical organization of the total gene diversity differed significantly between species. For instance, in Atlantic salmon Salmo salar and rainbow trout S. gairdneri a considerably larger proportion of the total genetic variation is located within populations than in brown trout $S$, trutta. Thus, although $P$ and $\bar{H}_{L}$ estimates based on one or a few samples are probably usually not valid for the species as such, the degree of inaccuracy may vary between species. This effect should be borne in mind whenever interspecific comparisons of gene diversity are undertaken.
The present data, based on 2 samples, are thus regarded as indicative, only, for the overall level of genetic variation in the capelin. However, the general impression of low genetic variability is as expected for a salmoniform species with a polar (Arctic) distribution (Cross and Ward, 1980; Smith and Fujio, 1982).

\section{Genetic differences between samples}

The observed genotypic distributions at the 4 polymorphic loci in samples from Areas A and B are listed in Table 2. The same loci were polymorphic in the fjord stock and the oceanic stock. At the AAT-2 and MDH-1 loci, the same alleles were found in both samples, and in almost equal frequencies. At $S O D, 2$ specimens out of 120 from Area A were heterozygotes $S O D$ (6.1/5.5). The SOD (5.5) allele was not found among the 60 individuals from Area B. This outcome is, however, far from being statistically significant (Fisher's exact test: $\mathrm{P}=0.444$ ).

At PGI-2, the frequency of the most common allele PGI-2 (6.8) was quite similar in the 2 samples. At this locus 1 variant allele, PGI-2 (7.0), was generally present while 2 alleles, PGI-2 (6.5) and PGI-2 (8.4), were observed only in the sample from Area $A$, and 1 allele, PGI-2 (6.9), only in the sample from Area B. As revealed by a G-test of allele proportions $(5 \times 2$ contingency table) this observed difference in allele distribution is not statistically significant $(G=6.544$, d.f. $=4, P=0.162$ )

Thus, we found no genetic evidence for reproductive isolation between the fjord stock and the oceanic stock of capelin investigated in this study, and the calculated mean genetic distance $\left(\bar{D}_{i}\right.$ Nei, 1975) between samples from Areas $A$ and $B$ is, accordingly, small $(\bar{D}=0.00002$ based on 18 loci).

Acknowledgements. We are indepted to S. Espelid, Institute of Fisheries, University of Tromsö, for providing capelin samples, and to J. Wallace, same address, for valuable criticism and linguistic corrections. This study was supported by grants from the Norwegian Fisheries Research Council (I. 309.07) and from Nansenfondet.

\section{LITERATURE CITED}

Allendorf, F. W., Mitchell, N., Ryman, N., Ståhl, G. (1977). Isozyme loci in brown trout (Salmo trutta L.): detection and interpretation from population data. Hereditas 86: $179-190$

Allendorf, F. W., Utter, F. M. (1979). Population genetics. In: Hoar, W S., Randall, D. J., Brett, J. R. (eds.) Fish physiology, Vol. 8, Bioenergetics and growth. Academic Press, New York, p. 407-454 
Cross, T F., Ward, R. D. (1980). Protein variation and duplicate loci in the Atlantic salmon, Salmo salar L. Genet. Res. 36: $147-165$

Darnall, D. W., Klotz, I. M. (1975). Subunit constitutions of proteins: a table. Archs Biochem. Biophys. 166: 651-682

Lewontin, R. C. (1974). The genetic basis of evolutionary change. Columbia University Press, New York

Mork, J., Haug, T. (1983). Genetic variation in halibut Hippoglossus hippoglossus (L.) from Norwegian waters. Hereditas 98: in press

Nei, M. (1973). Analyses of gene diversity in subdivided populations. Proc. natn. Acad. Sci. U.S.A. 70: 3321-3323

Nei, M. (1975). Molecular population genetics and evolution.
North-Holland Publ. Co./Am. Elsevier Publ. Co., New York

Nei, M., Roychoudhury, A. K. (1972). Gene differences between Caucasian, Negro and Japanese populations. Science, N. Y 177: 434-436

Nevo, E. (1978). Genetic variation in natural populations: patterns and theory. Theor Populat. Biol. 13: 121-177

Ryman, N. (1983). Patterns of distribution of biochemical genetic variation in salmonids; differences between species. Aquaculture: in press

Smith, P. J., Fujio, Y. (1982). Genetic variation in marine teleosts: high variability in habitat specialists and low variability in habitat generalists. Mar. Biol. 69: 7-20

This paper was submitted to the editor; it was accepted for printing on March 8, 1983 